To the Editors:

\title{
Primary hypomagnesaemia with secondary hypocalcaemia in an infant
}

A 2-month old girl was transferred from General Hospital Kurunegala to the Lady Ridgeway Hospital (LRH) in September 1998 with a history of uncontrolled generalised fits from the age of 6 weeks. Before 6 weeks the baby.had been apparently normal. She is a product of a first cousin marriage. The other two children are in good health. The birth and neonatal histories were normal. The birth weight was $3.65 \mathrm{~kg}$. The baby was treated with phenobarbitone at the Kurunegala Hospital with little effect. She was sucking well throughout. A lumbar puncture done at the Kurunegala Hospital revealed a normal CSF.

At the LRH after taking blood for investigation, the baby was started on a combination of calcium gluconate, magnesium sulphate and pyridoxine. On the third day of therapy fits were controlled. The blood glucose, blood urea and serum electrolytes were normal but the serum calcium level was $1.23 \mathrm{mmol} /$ (normal range 2.1-2.7 mmol/). After one week of therapy the magnesium sulphate and pyridoxine were omitted. Six days later the baby again developed fits. The serum calcium at this stage was 1.75 mmol/l and the serum magnesium $0.85 \mathrm{mg} / \mathrm{dl}$ (normal range 1.70-2.19 mg/dl). Magnesium sulphate was restarted and within a few days the fits were controlled. After a few days the calcium gluconate was omitted and the baby was treated solely with magnesium sulphate. After 2 weeks of therapy the serum calcium was $2.14 \mathrm{mmol} / \mathrm{l}$ and the serum magnesium $1.41 \mathrm{mg} / \mathrm{dl}$. After 2 months of therapy with magnesium sulphate the serum calcium was $2.35 \mathrm{mmol} / \mathrm{l}$ and the serum magnesium $1.79 \mathrm{mg} / \mathrm{dl}$. There was no recurrence of fits. A diagnosis of primary hypomagnesaemia with secondary hypocalcaemia was made.

Primary hypomagnesaemia with secondary hypocalcaemia is a rare genetic disorder characterised by recur- rent tetany or convulsions in early infancy, which are refractory to calcium supplementation but respond to magnesium treatment (1). In most patients primary hypomagnesaemia is caused by a selective defect of magnesium absorption in the small intestine, but the basic underlying mechanism of this disease is unknown (2). Primary hypomagnesaemia has been previously described in at least $\mathbf{3 0}$ patients and is thought to be an autosomal recessive disease $(3,4)$. The mechanism leading to hypocalcaemia in hypomagnesaemia is controversial. Several factors have been proposed, such as end organ unresponsiveness to parathyroid hormone, impaired synthesis and release of parathyroid hormone, and impaired formation of 25-dihydroxyvitamin D (5).

\section{References}

1. Shalev H, Phillip M, Galil A, Carini R, Landau D. Clinical presentation and outcome in primary hypomagnesaemia. Archives of Diseases in Childhood 1998; 78: 127-30.

2. Milla PJ, Aggett PJ, Wolff $\mathrm{OH}$. Studies in primary hypomagnesaemia: evidence for defective carrier - mediated small intestinal transport of magnesium. Gut 1979; 20: 1028-33.

3. Abdulrazzaq YM, Smigura FC, Wettrell G. Primary hypomagnesaemia: report of 2 cases and review of literature. European Journal of Paediatrics 1989; 148: 459-61.

4. Dudin KI, Teebi AS. Primary hypomagnesaemia. A case report and literature review. European Journal of Paediatrics 1987; 146: 303-5.

5. Fatemi S, Ryzen E, Flores J. Effect of experimental human magnesium depletion on parathyroid hormone secretion and 1.25 dihydroxyvitamin D metabolism. Journal of Clinical Endocrinology and Metabolism 1991; 73: 1067-72.

G N Lucas, Paediatrician, and T G Y R Gunapala, Registrar, Lady Ridgeway Hospital, Colombo. 